\title{
New deformation, metamorphic and geochronological data on the Aiguilles-Rouges massif (Alpine External Crystallin massifs, France). A reappraisal of the Variscan tectono-metamorphic evolution in the Alpine Western External Crystallin massifs
}

Jonas Vanardois ${ }^{1}$, Pierre Trap ${ }^{1}$, Françoise Roger ${ }^{2}$, Fabrice Barou ${ }^{2}$, Pierre Lanari ${ }^{3}$, Didier Marquer $^{1}$, Jean-Louis Paquette ${ }^{4}$, Jérémie Melleton ${ }^{5}$, and Kévin Fréville ${ }^{1}$

${ }^{1}$ UMR 6249 Chrono-environnement, Université de Bourgogne-Franche-Comté, 25030 Besançon, France

${ }^{2}$ Laboratoire Géosciences Montpellier (CNRS-UMR 5243), Campus Triolet, Université Montpellier, 34095 Montpellier Cedex 5, France.

${ }^{3}$ Institute of Geological Sciences, University of Bern, 3012 Bern, Switzerland

${ }^{4}$ Laboratoire Magmas et Volcans (CNRS-UMR 6524), Campus Universitaire des Cézeaux, 63178 Aubière Cedex, France

${ }^{5}$ BRGM-French Geological Survey, 3 Avenue Claude Guillemin, 45100, Orléans, France.

The Aiguilles-Rouge Massif (ARM) is one of the Western External Crystallin Massifs (ECM) of the French Alps. Similarly to the other ECMs, the ARM exposes a Variscan basement made of migmatitic ortho- and paragneisses and micaschists that hold metric boudins of retrograded eclogites, amphibolites and serpentinites. Upward, low-grade and weakly metamorphosed Late-Carboniferous terrigenous sediments overly the Variscan basement. Deformation and metamorphism occurred between 330 and 300 Ma. The whole ARM is structured by a main N-S to NE-SW trending and vertical foliation formed in response to a regional dextral transpression. The tectonic significance of the ARM's high-pressure rocks in the Variscan belt realm as relics of a subduction zone, pieces of crustal root of an orogenic plateau or overpressure phenomenon along a high-strain zone is still highly debated. A question that also remains is how eclogite

Pressure-Temperature-time-Deformation history ( $\mathrm{P}-\mathrm{T}-\mathrm{t}-\mathrm{D}$ path) relates to the metamorphic paths recorded in the surrounding migmatitic rocks. In this contribution we present new structural and microstructural (EBSD data) observations that give us a detailed vision of the partitioning of the crustal scale deformation during Late-Variscan time. Three main deformations, named D1, D2 and D3, have been recognized in the gneissic core of the ARM. $\mathrm{D} 1$ is relictual and corresponds to a flatlying S1 foliation that is only visible in the high grade metasedimentary rocks and preserved in low- D2 strain domains. D1 is associated with a partial melting metamorphic event M1. D2 is characterized by three main orientations of planar fabrics that are oriented in directions N160, N0 and N20. These planar fabrics are interpreted as S2-C2-C2' related to anastomosed system developed under a bulk dextral transpression. D2 shearing becomes more penetrative toward the NE, where it is associated to local partial melting. D3 corresponds to the development of a flatlying S3 cleavage together with the folding of vertical D2 foliations. The D3 is linked to a regional vertical shortening, associated to few liquid injections. These partial melting conditions occurring during D1, D2 and D3 deformations may unravel a continuum of these three deformations during a short period of time. Processing of new thermobarometric and LA-ICP-MS U-Pb geochronological data on eclogites, surrounding rocks and migmatites are currently in progress. The new 
obtained results will be presented in addition to the structural and metamorphic data in order to discuss the P-T-t-D path of the deeply buried metasedimentary rocks, migmatites and preserved eclogites. 